\title{
IMPROVEMENT OF THE COMPANY'S ELECTRONIC ARCHIVE INFORMATION SYSTEM
}

\author{
Yu.V. Podpovetnaya ${ }^{1,2}$, y-u-l-i-a-v-a-l@mail.ru, \\ A.M. Najmiddinov ${ }^{3}$, asadullo-tj@mail.ru, \\ L.Yu. Ovsyanitskaya ${ }^{1,4}$, larovs@rambler.ru, \\ A.D. Ovsyanitskiy', alexao12@rambler.ru \\ ${ }^{1}$ Financial University under the Government of the Russian Federation (Ural branch), \\ Chelyabinsk, Russian Federation, \\ ${ }^{2}$ South Ural State University, Chelyabinsk, Russian Federation, \\ ${ }^{3}$ Tajik State Finance and Economics University, Dushanbe, Republic of Tajikistan, \\ ${ }^{4}$ International Institute of Design and Service, Chelyabinsk, Russian Federation
}

\begin{abstract}
The documentation archive is an important base of accumulated knowledge and development of a company engaged in project activities. Given that the archive has diverse functions, it is quite difficult to organize clear work on structured storage, ensuring reliability of storage, confidentiality and differentiation of access rights, tracking the history of changes to documents, quick and easy search. Therefore, the article pays particular attention to solving the problem of improving the information system of an electronic archive of an enterprise.

To solve the indicated problem, within the framework of this article, the functional requirements to the electronic archive of the enterprise are identified, the compliance of the existing system with the functional requirements is analyzed, measures are proposed to increase the efficiency of managing the electronic archive of documents.

Based on the study of the electronic archive system of scientific and technical documentation (STD), the analysis and modeling of the structure of the electronic archive are carried out. The structure of the organizational part of the electronic STD archive, which regulates the life cycle of the document and the technical part responsible for the storage of documentation, is revealed. In order to improve the information system of the electronic archive of the enterprise, the models of business processes "Information Support", "Management of storage and receipt of information" were built and the effectiveness of the developed models was evaluated.

A comparative analysis of typical solutions of the electronic archive system is presented, which includes software products of the electronic archive STD: LOTSMAN: PLM Archive, STOR-M3 and TechnologiCS. As a result of the analysis, the correspondence of typical software products to the constructed business process models according to the required functionality is shown and the optimal system of electronic STD archive for implementation at the enterprise is selected.
\end{abstract}

Keywords: information system, electronic archive, software products, scientific and technical documentation, enterprise business processes, modeling.

\section{Introduction}

There are various methodologies for the effective management of an IT project. These methodologies determine the composition of the project participants, their roles, tasks and ways of interaction. The features of an IT project include: changing the initial requirements for an IT project during deve_lopment, any of the project participants can be simultaneously involved in other IT projects, a high risk of failure of an IT project, and rapid obsolescence of technologies used in IT projects. Despite the fact that new management technologies are invented to improve the efficiency of IT project management, they all have common features. One of them is maintaining and storing project documentation. To realize the possibility of storing documentation, there are various systems. At large enterprises, these are electronic document archive systems. The enterprise engaged in project activities, as a result, issues a package of documents with a graphical representation of the models, structured text, scientific and technical documentation, etc. The documentation archive is an important base of accumulated knowledge and development of the organization. Since the archive has diverse functions, it is very difficult to organize clear work on structured storage, ensuring reliability of storage, confidentiality and dif- 


\section{Управление в социально-экономических системах}

ferentiation of access rights, tracking the history of document changes, and quick and convenient search. Therefore, the solution to the problem of organizing an electronic archive is relevant. Thus, the effectiveness of working with electronic document systems directly affects the effectiveness of IT project management, regardless of the chosen methodology. To solve the indicated problem within the framework of this article it is necessary:

1) to identify the functional requirements for the electronic archive of the enterprise;

2) to analyze the compliance of the existing system with functional requirements;

3) we will offer measures to improve the efficiency of managing the electronic archive of documents.

\section{Analysis of the electronic archive system of scientific and technical documentation}

The electronic archive of scientific and technical documentation (STD) consists of two parts: the organizational part, which regulates the life cycle of the document and the technical part, which is responsible for the storage of documentation. The organizational part of the STD archive is a set of orders and regulations for the interaction (exchange of information) of thematic units, standard control and the archive throughout the development cycle of design, program and technical documentation. The technical part is implemented as a Subversion (SVN) version control system server $[1,2]$.

The structure of the electronic archive is shown in Fig. 1.

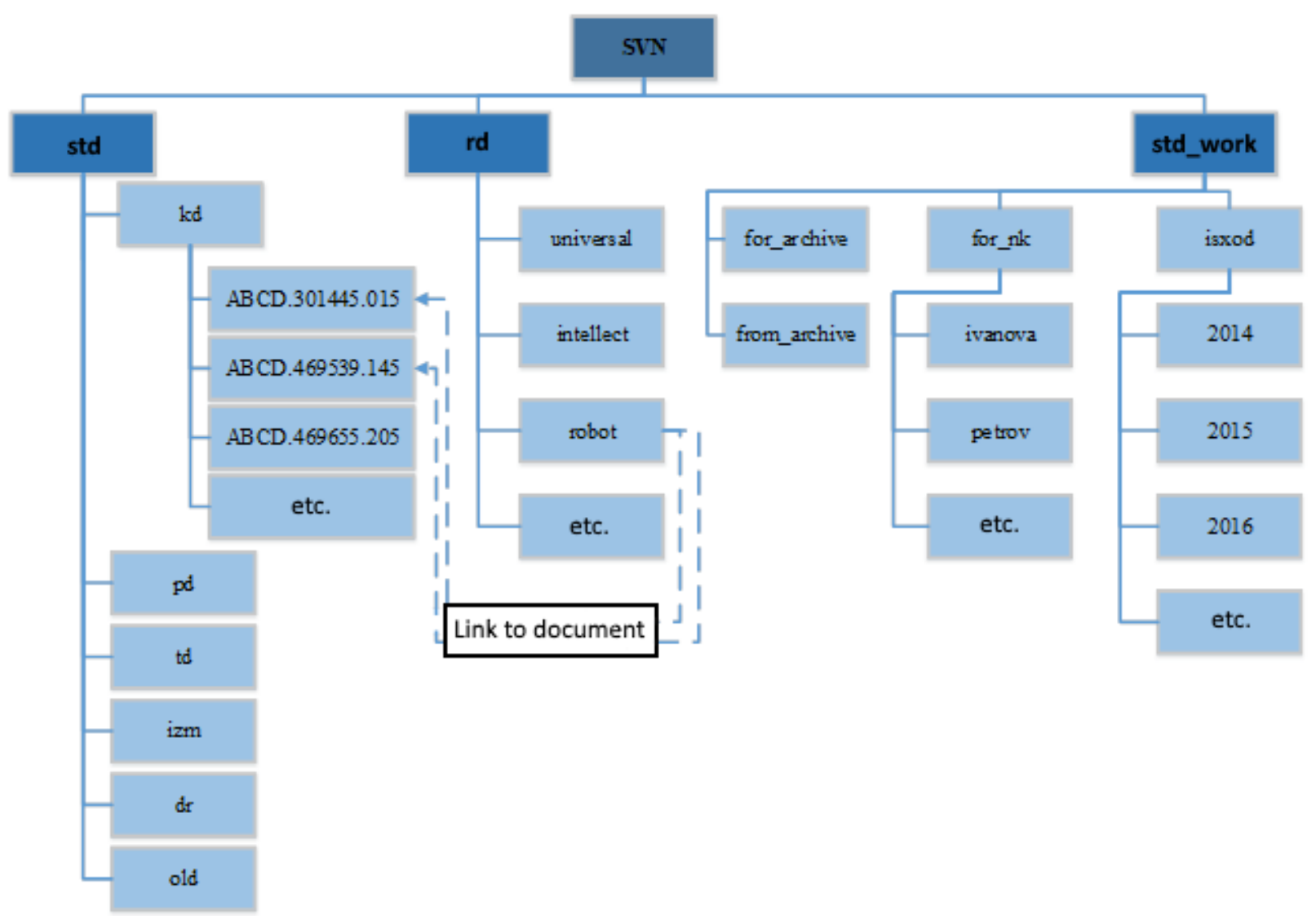

Fig. 1. The structure of the electronic archive

To organize an electronic archive on the electronic archive storage server, three sections are allocated - std, std_work and rd. The software on the server that provides the archive has an authentication mechanism by login and password, as well as channel encryption (HTTPS protocol). This mechanism provides fixation of the time for making changes and the login used for this, and also allows you to track the details of the changes made by comparing with previous versions of the file.

The name of the technical documentation files in the electronic archive has a strict format. This format includes: project identifier; decimal number characteristic; serial archive number; type of document; file version number; file extension. The file name structure should be as shown in Fig. 2. 


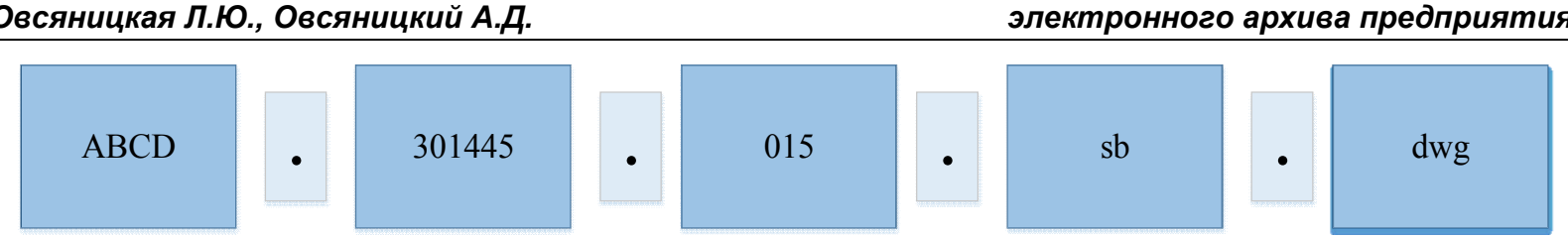

Fig. 2. An example of the structure of names of STD files in the archive

The responsibility for the correct construction of the structure of the transmitted documentation lies with the developer. For automated assessment of the correctness of the transmitted data, software is implemented that must be provided to all developers. Data is exported from the archive using an automation tool that allows you to complete the documentation by bypassing the links in the head directory with the further construction of the necessary hierarchy of the complete set of documentation. An example of the structure of the documentation provided in the archive is shown in Fig. 3.

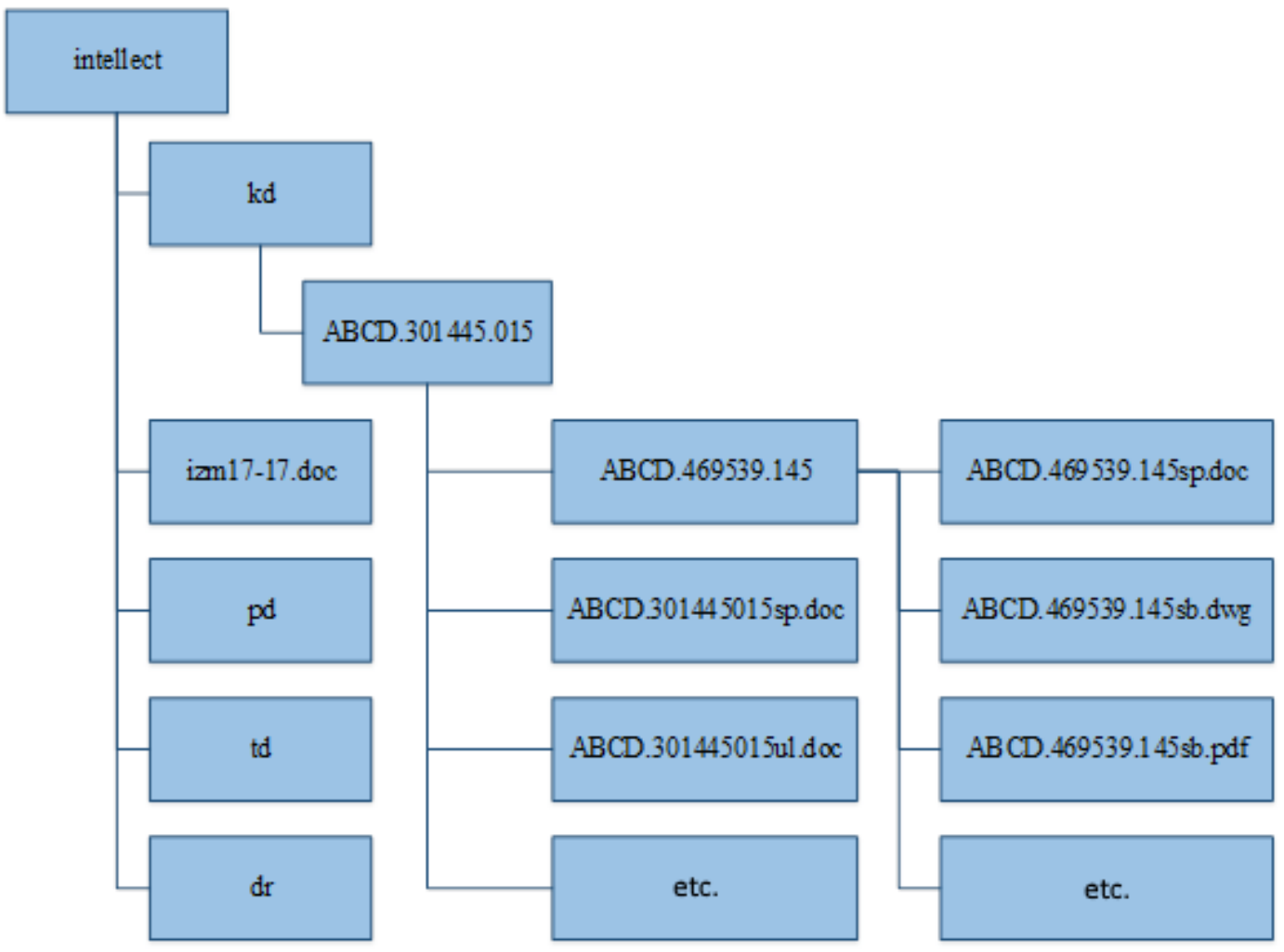

Fig. 3. An example of the documentation structure for the archive

To help you work with the electronic archive of documents, there is specially developed software that facilitates checking the compliance of documents with regulations and transferring documents to the archive. In the process of analyzing the existing system for organizing the electronic STD archive at the enterprise, the following disadvantages were identified [3]:

- the life cycle of electronic documents is determined only by the regulations and orders of the leadership, which increases the likelihood of error as a human factor in the process of creating and maintaining documentation;

- extremely complex and confusing manual for using the system;

- lack of automatic distribution of notifications of interested parties about new documents;

- lack of control over the execution time of the stages of approval and approval of documents;

- when a user is denied access to documents, they do not automatically disappear from the local user repository;

- due to the copying of documents between folders, the history of documentation approvals is divided into different parts;

- lack of built-in support for directories;

- lack of verification of completeness of documents. 


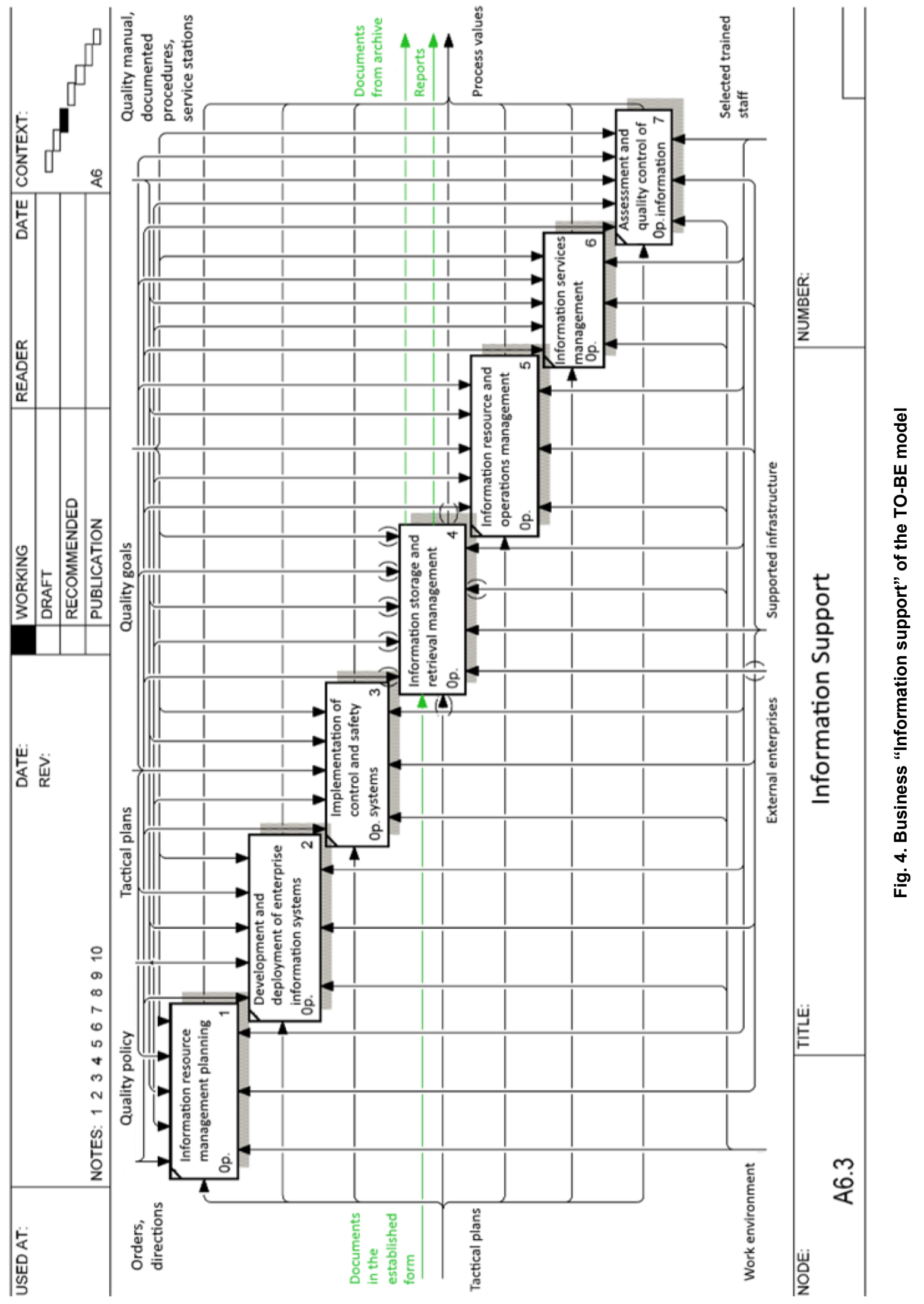




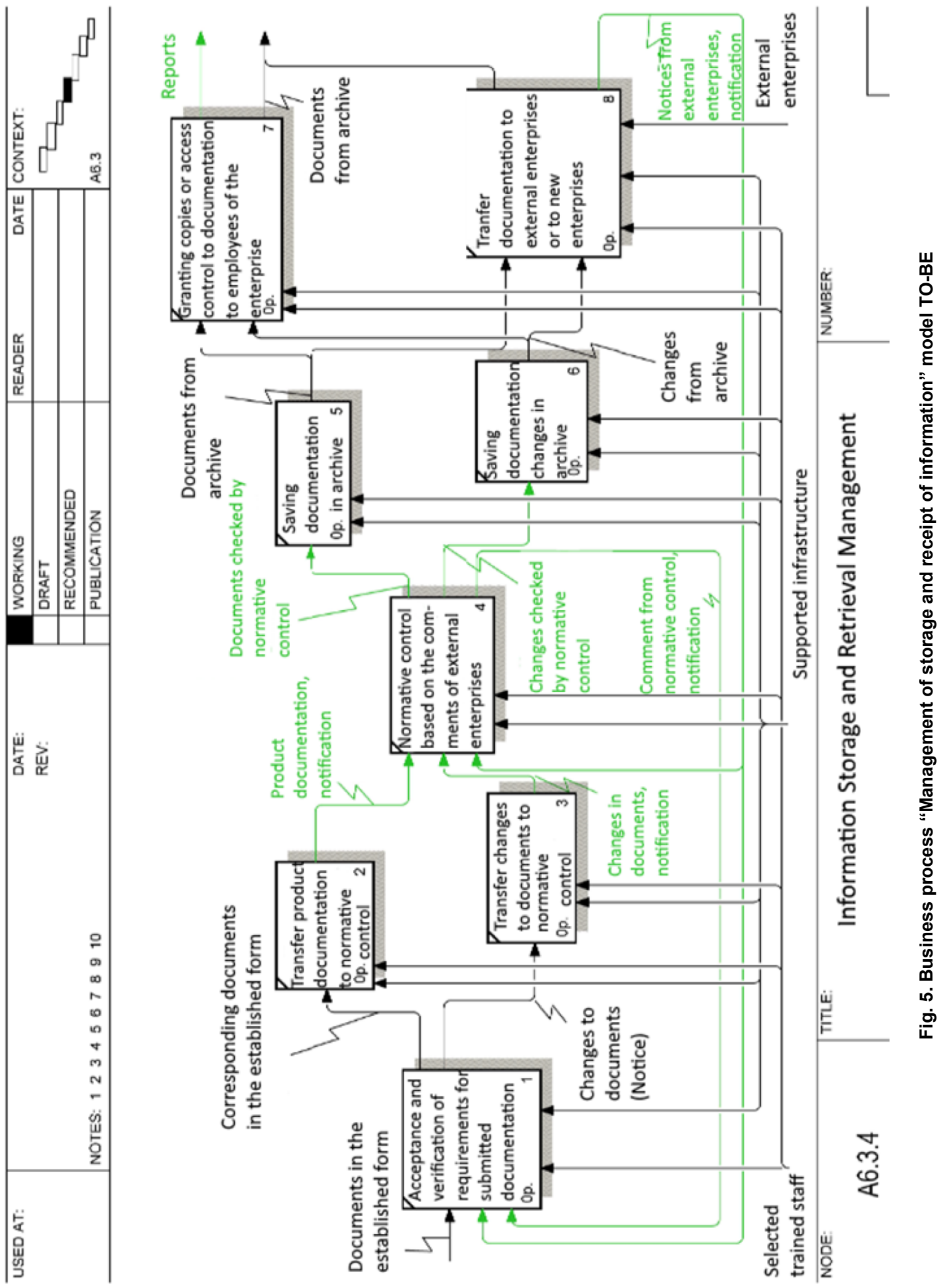




\section{Управление в социально-экономических системах}

Practice shows that the amount of accumulated information is about one hundred thousand documents and this figure is increasing every day. The influence of the identified shortcomings causes negative consequences expressed in the employees' mistakes when creating and maintaining documents, disrupting the processing of documents, gaining unauthorized access to information, providing outdated documents to interested parties, the result of which is unnecessary time and money. Due to the aforementioned shortcomings, it was decided to consider alternative ready-made solutions of the electronic archive system of scientific and technical documentation for implementation $[4 ; 5]$.

Description of the TO-BE functional model of the relevant business processes. As a result of the analysis of the AS-IS system and determination of its shortcomings, the TO-BE model was developed, shown in Fig. 4-5.

Table 1 shows a comparative analysis of the AS-IS and TO-BE models.

Table 1

\begin{tabular}{|c|c|c|}
\hline Function & AS-IS & TO-BE \\
\hline Ability to store documents & \multicolumn{2}{|c|}{ Supported } \\
\hline $\begin{array}{l}\text { The ability to easily and quickly } \\
\text { search for documents }\end{array}$ & $\begin{array}{l}\text { Search by title and content of } \\
\text { the document is possible }\end{array}$ & $\begin{array}{l}\text { You can search by name, con- } \\
\text { tent, type, related documents }\end{array}$ \\
\hline $\begin{array}{l}\text { Versioning of documents, the ability } \\
\text { to view the history of documents and } \\
\text { projects }\end{array}$ & $\begin{array}{l}\text { There is a difficulty viewing } \\
\text { the full history of the document }\end{array}$ & Fully supported \\
\hline $\begin{array}{l}\text { Possibility of flexible adjustment of } \\
\text { the document life cycle-document } \\
\text { routing }\end{array}$ & $\begin{array}{l}\text { Configured exclusively by } \\
\text { internal regulations }\end{array}$ & $\begin{array}{l}\text { Ability to automatically con- } \\
\text { figure the document route }\end{array}$ \\
\hline $\begin{array}{l}\text { Differentiation of access rights } \\
\text { between users }\end{array}$ & $\begin{array}{l}\text { The ability to obtain previous } \\
\text { versions of a document, even if } \\
\text { there is no access to it }\end{array}$ & Fully supported \\
\hline Ability to notify user about changes & Absent & Fully supported \\
\hline $\begin{array}{l}\text { Control over the execution of docu- } \\
\text { ment processing }\end{array}$ & Absent & Fully supported \\
\hline $\begin{array}{l}\text { Maintenance and use of electronic } \\
\text { directories }\end{array}$ & Absent & Fully supported \\
\hline $\begin{array}{l}\text { Checking the completeness of docu- } \\
\text { ments }\end{array}$ & $\begin{array}{l}\text { Performed using specially de- } \\
\text { veloped software }\end{array}$ & Fully supported \\
\hline Making report & Absent & $\begin{array}{l}\text { Project and document reports } \\
\text { supported }\end{array}$ \\
\hline Integration with other systems & \multicolumn{2}{|c|}{ Supported } \\
\hline Digital Signature Support & Absent & Fully supported \\
\hline
\end{tabular}

Based on the AS-IS model and the requirements for the TO-BE model, we can draw intermediate conclusions that the existing system does not meet all the necessary requirements for quick and convenient search, the ability to view the history of documents and projects, flexible configuration of document routes, differentiation of access rights, lack of access notifications to users, control over the execution of document processing, the lack of directories, the lack of reports and the absence of an digital signature. The solution to this problem is to replace the existing system [6].

The introduction of the TO-BE model will allow eliminating the mistakes of employees when creating and maintaining documents, speeding up access to information, viewing the history of documents and projects, adjusting document routes, controlling the timing of processing documents, eliminating unauthorized access to information, notifying users of changes, and providing interested parties with relevant information the documentation. To replace the existing system, we consider the main characteristics of several systems of the electronic archive of scientific and technical documentation [7].

Comparative analysis of typical solutions of the electronic archive system. Typical software products of the electronic STD archive are: LOTSMAN: PLM Archive, STOR-M3 and TechnologiCS. Let's compare typical information systems for the correspondence of the constructed TO-BE model with 
the required functionality: the ability to store documents, the ability to easily and quickly search for documents, the versioning of documents, the ability to view the history of documents and projects, the ability to flexibly configure the document life cycle, differentiation of access rights between users, the ability to notify the user about changes in the system, monitoring the execution of document processing, maintaining and using electronic directories, about ERKA completeness of documents, reporting, integration with other systems, with digital signatures.

We will carry out a comparative functional analysis of the considered systems based on certain requirements in the TO-BE model. The result of this analysis should be the choice of the most suitable system for implementation in the enterprise. The results of the analysis are presented in Table 2.

Table 2

\begin{tabular}{|c|c|c|c|}
\hline Function & $\begin{array}{l}\text { LOTSMAN: } \\
\text { PLM Archive }\end{array}$ & STOR-M3 & TechnologiCS \\
\hline Ability to store documents & + & + & + \\
\hline $\begin{array}{l}\text { The ability to easily and quickly search } \\
\text { for documents }\end{array}$ & + & + & + \\
\hline $\begin{array}{l}\text { Versioning of documents, the ability to view } \\
\text { the history of documents and projects }\end{array}$ & $\begin{array}{l}+/- \text { (no project } \\
\text { history) }\end{array}$ & + & + \\
\hline $\begin{array}{l}\text { Possibility of flexible adjustment of } \\
\text { the document life cycle - document routing }\end{array}$ & + & + & + \\
\hline $\begin{array}{l}\text { Differentiation of access rights between } \\
\text { users }\end{array}$ & $\begin{array}{l}+/-(\text { predefined } \\
\text { roles })\end{array}$ & + & + \\
\hline Ability to notify user about changes & + & + & + \\
\hline $\begin{array}{l}\text { Control over the execution of document } \\
\text { processing }\end{array}$ & - & + & + \\
\hline Maintenance and use of electronic directories & + & + & + \\
\hline Checking the completeness of documents & + & + & + \\
\hline Making report & + & + & + \\
\hline Integration with other systems & + & + & + \\
\hline Digital Signature Support & + & + & + \\
\hline
\end{tabular}

As a result of a comparative analysis of typical systems according to functional requirements, the TechnologiCS system was selected for implementation. TechnologiCS information system meets the requirements of the TO-BE process since allows you to: store documents, simple and quick search of documents, store different versions of documents and projects, view the history of documents and projects, flexibly configure the life cycle of documents, delimit access rights between users, notify users of changes, control document processing, use electronic directories, check the complexity of the documents, prepare reports, integrate data with other systems, sign documents with an electronic digital signature.

\section{Conclusions}

In conclusion, we note that the introduction of automated electronic archive systems is not only a way to optimize the internal processes of the enterprise, but also a significant advantage in a competitive environment. Quick, timely obtaining of up-to-date knowledge in the form of developments from the archive accelerates the work of the enterprise and allows you to stay ahead of the competition when making operational and strategic decisions.

In the course of solving the problem of improving the electronic archive system of the enterprise, the following results were obtained.

1. The requirements for the electronic archive system of the enterprise are analyzed:

- the ability to store documents;

- the ability to easily and quickly search for documents;

- versioning of documents, the ability to view the history of documents and projects;

- the ability to flexibly configure the life cycle of a document; 


\section{Управление в социально-экономических системах}

- differentiation of access rights between users;

- the ability to notify the user of changes;

- control over the execution of document processing;

- maintaining and using electronic directories;

- verification of completeness of documents;

- reporting;

- integration with other systems;

- support for digital signature.

2. Identified inconsistencies of the current system with the necessary functional requirements:

- the life cycle of electronic documents is determined only by the regulations and orders of management;

- extremely complex and confusing manual for using the system;

- lack of automatic distribution of notifications of interested parties about new documents;

- lack of control over the execution time of the stages of approval and approval of documents;

- when a user is denied access to documents, they do not automatically disappear from the local user repository;

- due to the copying of documents between folders, the history of documentation approvals is divided into different parts;

- lack of built-in support for directories;

- lack of verification of completeness of documents.

3. The optimal system of TechnologiCS electronic archive has been determined, the implementation of which in the enterprise will allow:

- reduce the cost of processing documents;

- increase the efficiency of an electronic archive employee by reducing the employee's working time for processing documents;

- increase the speed of processing documents through the use of directories and reduce the processing time of documents;

- accelerate access to information and search for documents;

- improve the skills of archive employees;

- optimize the routes of electronic documents in the archive;

- establish process control;

- notify users of system changes;

- simplify the process of working with documents.

\section{References}

1. Varfolomeeva A.O., Romanov V.P., Koryakovsky A.V. Informatsionnye sistemy predpriyatiya [Information Systems of the Enterprise.]. Moscow, SIC INFRA-M Publ., 2016. 283 p.

2. Grekul V.I., Korovina N.L., Kupriyanov Yu.V. Proektnoe upravlenie v sfere informatsionnykh tekhnologiy [Project Management in the Field of Information Technology]. Moscow, BINOM. Knowledge Laboratory Publ., 2017. 336 p.

3. Demchenko S.A. [Evaluation of Economic Efficiency in the Implementation of Electronic Archive and Document Management Systems in Design Organizations]. Electronic Scientific Journal APRIORI. Series: Natural and Technical Sciences, 2016, no. 6, pp. 1-7. (in Russ.)

4. Eliferov V.G. Biznes-protsessy: reglamentatsiya i upravlenie [Business Processes: Regulation and Management]. Moscow, INFRA-M Publ., 2017. 319 p.

5. Zabotina N.N. Proektirovanie informatsionnykh sistem [Designing of Information Systems]. Moscow, INFRA-M Publ., 2014. 331 p.

6. Zolotukhina E.B., Krasnikova S.A., Vishnya A.S. Modelirovanie biznes-protsessov. Kratkiy konspekt lektsiy [Modeling of Business Processes. Short Lecture Notes]. Moscow, INFRA-M Publ., 2017. 79 p.

7. Podpovetnaya Yu.V., Podpovetny A.D. [To the Issue of Information Support of the Product Life Cycle Management System]. Management in Modern Systems, 2017, no. 1 (12), pp. 25-31. (in Russ.) 


\title{
СОВЕРШЕНСТВОВАНИЕ ИНФОРМАЦИОННОЙ СИСТЕМЫ ЭЛЕКТРОННОГО АРХИВА ПРЕДПРИЯТИЯ
}

\author{
Ю.В. Подповетная ${ }^{1,2}$, А.М. Наджмиддинов ${ }^{3}$, \\ Л.Ю. Овсяницкая ${ }^{1,4}$, А.Д. Овсяницкий \\ ${ }^{1}$ Финансовый университет при Правительстве РФ (Уральский фрилиал), \\ г. Челябинск, Россия, \\ ${ }^{2}$ Южно-Уральский государственный университет, г. Челябинск, Россия, \\ ${ }^{3}$ Таджикский государственный фринансово-экономический университет, \\ е. Душанбе, Республика Таджикистан, \\ ${ }^{4}$ Международный институт дизайна и сервиса, г. Челябинск, Россия
}

\begin{abstract}
Архив документации является важной базой накопленных знаний и разработок предприятия, занимающегося проектной деятельностью. Учитывая, что архив обладает многообразными функциями, достаточно сложно организовать четкую работу по структурированному хранению, обеспечению надежности хранения, конфиденциальности и разграничению прав доступа, отслеживанию истории изменения документов, быстрому и удобному поиску. Поэтому в статье особое значение уделено решению проблемы по совершенствованию информационной системы электронного архива предприятия.

Для решения обозначенной проблемы в рамках данной статьи выявлены функциональные требования к электронному архиву предприятия, проанализировано соответствие существующей системы функциональным требованиям, предложены мероприятия по повышению эффективности управления электронным архивом документов.

На основе исследования системы электронного архива научно-технической документации (НТД) проведен анализ и моделирование структуры электронного архива. Выявлена структура организационной части электронного архива НТД, регламентирующая жизненный цикл документа и технической части, отвечающая за хранение документации. С целью совершенствования информационной системы электронного архива предприятия построены модели бизнес-процессов «Информационное обеспечение», «Управление хранением и получением информации» и проведена оценка эффективности разработанных моделей.

Представлен сравнительный анализ типовых решений системы электронного архива, к которым отнесены программные продукты электронного архива НТД: ЛОЦМАН:PLM Архив, STOR-M3 и TechnologiCS. B результате проведенного анализа показано соответствие типовых программных продуктов построенным моделям бизнес-процессов по требуемому функционалу и выбрана оптимальная система электронного архива НТД для внедрения на предприятии.

Ключевые слова: информационная система, электронный архив, программные продукты, научно-техническая документация, бизнес-процессы предприятия, моделирование.
\end{abstract}

\section{Литература}

1. Варфоломеева, А.О. Информачионные системы предприятия / А.О. Варфоломеева, В.П. Романов, А.В. Коряковский. - М.: НИЦ ИНФРА-М, 2016. -283 c.

2. Грекул, В.И. Проектное управление в сфере информационных технологий / В.И. Грекул, Н.Л. Коровина, Ю.В. Куприянов. - М.: БИНОМ. Лаборатория знаний, 2017. - 336 c.

3. Демченко, С.А. Оиенка экономической эффективности при внедрении систем электронного архива и документооборота в проектных организачиях / С.А. Демченко // Электронный научный журнал «APRIORI. Серия: Естественные и технические науки». - 2016. - № 6. - C. 1-7.

4. Елиферов, В.Г. Бизнес-процессы: регламентация и управление. - М.: ИНФРА-М, 2017. - 319 c.

5. Заботина, Н.Н. Проектирование информационных систем / Н.Н. Заботина. - М.: НИЦ ИНФРА-М, 2014. - 331 c.

6. Золотухина, Е.Б. Моделирование бизнес-процессов. Краткий конспект лекиий / Е.Б. Золотухина, С.А. Красникова, А.С. Вишня. - М.: КУРС: ИНФРА-М, 2017. - 79 с. 


\section{Управление в социально-экономических системах}

7. Подповетная, Ю.В. К вопросу информационного обеспечения системы управления жизненным ициклом продукиии / Ю.В. Подповетная, А.Д. Подповетный // Управление в современных системах. - 2017. - № 1 (12). - С. 25-31.

Подповетная Юлия Валерьевна, д-р пед. наук, доцент, зав. кафедрой математики и информатики, Финансовый университет при Правительстве РФ (Уральский филиал); профессор кафедры русского языка как иностранного, Южно-Уральский государственный университет, г. Челябинск; у-u-1-i-a-v-a-1@mail.ru.

Наджмиддинов Асадулло Мирзоевич, канд. физ.-мат. наук, зав. кафедрой математического моделирования и информации, Таджикский государственный финансово-экономический университет, г. Душанбе, Республика Таджикистан; asadullo-tj@mail.ru.

Овсяницкая Лариса Юрьевна, канд. техн. наук, доцент, зав. кафедрой математики и информатики, Международный институт дизайна и сервиса; доцент кафедры математики и информатики, Финансовый университет при Правительстве РФ (Уральский филиал), г. Челябинск; larovs@rambler.ru.

Овсяницкий Алексей Дмитриевич, студент Высшей школы электроники и компьютерных наук, Южно-Уральский государственный университет, г. Челябинск; alexao12@rambler.ru.

Поступила в редакцию 28 августа 2019 2.

\section{ОБРАЗЕЦ ЦИТИРОВАНИЯ}

Improvement of the Company's Electronic Archive Information System / Yu.V. Podpovetnaya, A.M. Najmiddinov, L.Yu. Ovsyanitskaya, A.D. Ovsyanitskiy // Beccник ЮУрГУ. Серия «Компьютерные технологии, управление, радиоэлектроника». - 2019. - Т. 19, № 4. C. $99-108$. DOI: $10.14529 /$ ctcr 190409

\section{FOR CITATION}

Podpovetnaya Yu.V., Najmiddinov A.M., Ovsyanitskaya L.Yu., Ovsyanitskiy A.D. Improvement of the Company's Electronic Archive Information System. Bulletin of the South Ural State University. Ser. Computer Technologies, Automatic Control, Radio Electronics, 2019, vol. 19, no. 4, pp. 99-108. DOI: $10.14529 /$ ctcr190409 